\title{
IMPLEMENTATION OF INNOVATIVE FORMS AND MODELS OF PUBLIC ADMINISTRATION IN THE SPHERE OF CULTURE IN UKRAINE
}

\author{
Marta Karpa ${ }^{1}$, Oleksandr Akimov², Vasyl Shykerynets ${ }^{3}$ \\ ${ }^{I}$ Doctor of Science (Public Administration), Associate Professor, Department of Management and Business \\ Administration, Vasyl Stefanyk Precarpathian National University, Ivano-Frankivsk, Ukraine, e-mail: \\ marta.karpa@ukr.net, ORCID: https://orcid.org/0000-0001-8141-4894 \\ ${ }^{2}$ Doctor of Science (Public Administration), Associate professor, Honored Economist of Ukraine, Professor \\ of the Department of Public Administration, Interregional Academy of Personnel Management, Kyiv, \\ Ukraine, e-mail: 1970aaa@ukr.net,ORCID: https://orcid.org/0000-0002-9557-2276 \\ ${ }^{3}$ Ph.D. (Public Administration), Associate Professor, Head of the Department of Social and Cultural Activity \\ Management, Show Business and Event Management, Vasyl Stefanyk Precarpathian National University, \\ Ivano-Frankivsk, Ukraine, vasyl.shykerynets@pnu.edu.ua, ORCID: https://orcid.org/0000-0002-6845-1639
}

\begin{abstract}
The article examines the actual problem of the development of the sphere of culture in Ukraine. Today, with the arrival and development of the state and civil society in Ukraine, a new model of state policy is being formed, which requires further improvement of the quality of public administration in the field of culture, its formation, style, methods and legal forms based on modern research. In these conditions, the main task of the functioning of public authorities and management of the sphere of culture, the latter must be solved in cooperation with state institutions, cultural intelligentsia and outstanding cultural figures, is to improve the principles and directions of culture, state policy, which is of great strategic importance for countries to develop and modernize. The aim of the article: to investigate the peculiarities of the implementation of innovative forms and models of state policy in the field of culture in Ukraine, using the best European experience in public administration in the field of culture. The research methodology: to solve the set research tasks, the following methods of cognition were used in the work: analysis and synthesis - to substantiate the need and disclose the essence of the implementation of state policy in the field of culture, as well as to examine the modern legal and regulatory framework of Ukraine, regulating the functioning of this area; structural and functional - to study the organizational structure of authorities in the sphere of culture; comparative analysis - to compare the characteristics of the cultural policy of Spain, Italy, France and Germany. The subject of the research is the peculiarities of the implementation of innovative forms and models of state policy in the field of culture in Ukraine, with the possibility of implementing the best European experience. Therefore, the article actively used the analysis to compare the characteristics of the cultural policy of Spain, Italy, France and Germany. As a result of the study, conclusions were drawn regarding the possible use of diversification of the mechanism for financing the sphere of culture in Ukraine; the creation of cultural centers should be funded by government grants; the creation in Ukraine of functional and regulatory provisions obliging the authorities at the regional and local levels to involve leaders on the basis of an open competition and training in the field of cultural management to create opportunities for the cultural and social development of the state.
\end{abstract}

Keywords: public policy, public administration, innovation, sphere of culture, public authorities.

JEL Classification: H00, H83, Z18

Formulas: 0; fig.: 1; tabl.: 0; bibl.: 9. 
Introduction. Today the problem in the sphere of culture of Ukraine is the functional and organizational support for the implementation of state policy and the search for opportunities for the application of innovative models and forms in this area. The relevance of the study is due to the presence of problems and global transformations of the cultural environment and the transition from the traditional structural-institutional approach to the implementation of state policy in the field of Ukrainian culture to the functional and managerial, which are characterized by an innovative concept of the cultural sphere.

Literature Review. Ukrainian and foreign researchers paid attention to the problems of cultural development of society in different historical periods, in particular: M. Castells, C. Landry, F. Matarasso, A. Perotti, V. Bibler, M. Kagan, S. Krymsky, M. Mamardashvili, A. Mole, W. Weidlich, M. Castells . The theoretical and methodological foundations and definitions of certain aspects of state regulation of the cultural sphere are contained in the works of V. Andrushchenko, V. Bakumenko, A. Batishchev, I. Voronov, L. Vostryakov, A. Gritsenko, V. Karlova, M. Kiryushka, S. Kindzersky, P. Nadolishny, M. Proskurina, A. Svidzinsky, S. Chukut.

Aims. To investigate the peculiarities of the implementation of innovative forms and models of state policy in the field of culture in Ukraine, using the best European experience in public administration in the field of culture.

Methods. To solve the set research tasks, the following methods of cognition were used in the work: analysis and synthesis - to substantiate the need and disclose the essence of the implementation of state policy in the field of culture, as well as to examine the modern legal and regulatory framework of Ukraine, regulating the functioning of this area; structural and functional - to study the organizational structure of authorities in the sphere of culture; comparative analysis - to compare the characteristics of the cultural policy of Spain, Italy, France and Germany.

Results. At the moment, the processes that are taking place in Ukraine cannot be viewed in isolation, since, over time, they coincide with the global transformation of the cultural phenomenon itself. This opens up a real and unique opportunity for Ukraine to synchronize the development of the sphere of culture and views on the means and forms of state influence on the cultural process with the international community.

The main trends in the development of the sphere of culture in Ukrainian society are most often called:

- deepening the integration of national culture with the European and world cultural space;

- limiting the participation of the state in supporting the cultural sphere in the new market and economic conditions; 
- widening the gap in the level of cultural development between individual regions of the state [1].

At the same time, its shortcomings are most often called residual financing, insufficient awareness of the importance of the cultural sphere at the level of strategic management, a declarative legal framework, and among the main problems:

- conceptual and programmatic ambiguity of cultural policy at different levels of government;

- protection of national and cultural space in the context of globalization;

- low level of material and technical and staffing, and the like.

There are two main approaches to the implementation of state policy in the field of culture:

- traditional structural-institutional (it is also called systemic or resource), in which cultural policy is viewed through the prism of power, which is carried out by state authorities, local authorities and sometimes public organizations;

- functional and managerial, associated with a newer concept of the existence of the cultural and political process.

In fact, they are associated with the existence in the world of two paradigms of state policy, which are called "paternalistic" and "partner", but usually one of them does not exist in its pure form, and their components remain in constant interaction. In fact, we are talking only about rethinking a specific model in the process of choosing specific directions and instruments of state regulation in the field of culture, as well as in the implementation of cultural and political decisions.

The main models of state financing of the sphere of culture by foreign researchers have identified the following, which have received well-known names:

- state architect;

- state engineer;

- the inspiring state;

- patron state.

It is also important that the same country can simultaneously use additional models, so the classification put forward is not unwise.

In general, state policy in the sphere of culture of modern Ukraine can be described as a policy of a transitional type, in which the state is the main subject. The annual message of the President to the Verkhovna Rada of Ukraine emphasizes the importance of developing the sphere of culture and effective state policy in the field of modernizing Ukraine and consolidating the whole society, they are formulated according to its basic conceptual principles.

The Public Humanitarian Council chaired by the President of Ukraine is an effective mechanism that unites the efforts of the authorities and society in solving the problems of humanitarian and cultural development. This advisory institution 
provides access to participation in the process of developing a strategy for the humanitarian development of Ukraine, as well as decides tactical issues of cultural policy.

The Verkhovna Rada of Ukraine establishes the main legal framework and priorities of the state policy for the development of the cultural sphere and sets the budget for this industry every year. The Cabinet of Ministers of Ukraine ensures the implementation of this policy through the respective Vice Prime Minister.

This type of public policy is pre-based on the direct effect of the outcome on the strength of managerial action, usually does not work. At the same time, the rapid changes taking place in the modern world have caused the concept of sustainable development in the sphere of the state economy, making it determinative in all spheres of public life, including culture, the concepts of "change", "partnership" and "knowledge".

Ukraine has a rich cultural heritage, as well as a number of industries, by the nature of their activities can be considered "creative". The sphere of culture are important for the population of Ukraine, and also occupies a certain place in the world cultural heritage. In terms of regulating the development of the cultural sphere, one of the leading roles is played by the government, since it creates the necessary prerequisites for the preservation and development of national cultural values and goods, which serve as an important basis for the development of society as a whole and the upbringing of each individual.

The development of the sphere of culture and the proper state regulation of this sphere stimulate effective interaction between various social groups, and is also a key factor in the development of tourism. An additional impetus is created for the further socio-economic and political development of the state. Today, the sphere of culture is becoming increasingly integrated into all aspects of public life and the economy of the state, requiring more fruitful and in-depth interaction between different levels of government, society, as well as public and private institutions. Such interrelation was noted by scientists in the context of identifying the influence of international experience in the implementation of public administration in various fields, including the sphere of culture [2].

All this predetermines the need for a comprehensive analysis of modern trends in public administration in the sphere of culture and determining the directions of reforming this sphere in Ukraine.

One of the constitutional freedoms of citizens of Ukraine is "freedom of literary, artistic, scientific and technical creativity, protection of intellectual property, copyright, moral and material interests that arise in connection with intellectual activity in this industry" [3]. 
This provision is the basis for the process of state management of the sphere of culture, aimed at stimulating and supporting various manifestations of creative activity of the population of Ukraine, and consists in organizational support and creation of appropriate favorable conditions for the development, distribution, popularization of works of art, literature and other cultural benefits, dissemination of information about the past. and the current achievements of culture, the targeted use, preservation and protection of cultural values, cultural monuments and works of art in the state, promoting the growth of the level of culture of the Ukrainian nation, exercising leadership functions and monitoring the activities of subordinate organizations, institutions and cultural institutions of state ownership, which in general contributes to the satisfaction of the cultural needs of the citizens of Ukraine and the preservation of the national consciousness of the population.

By culture, which is an object of government, in a broad sense, we mean a set of various material and spiritual values and benefits created by society, which characterizes a certain level of its development in the country.

Cultural and artistic events in the state are carried out mainly by cultural institutions, which are museums, theaters, philharmonic societies, film demonstrators, club institutions, libraries, publishing houses, circuses, parks of culture and recreation, schools of aesthetic education, and the like.

In European practice, culture is not just an object of public administration, but is also considered as the basis for further socio-economic growth of the state, since it plays an important role in many aspects of the development of the state, in particular:

- in the development of intellectual resources of the state economy (ensuring the employment of citizens in the creative sectors, developing innovative potential in the state, stimulating innovation to ensure the production of competitive and high-quality products);

- in the sustainable development of the economy (the spread of the latest digital technologies, strengthening the relationship between the cultural, economic and environmental components of sustainable development);

- in the socially oriented development of the economy (culture is the basis for the development of the economy through strengthening intercultural dialogue and respect for cultural diversity, increasing the level of social cohesion in the process of cultural activities, increasing the role of the public sector in the social, cultural, economic development of the country).

In international practice, there are four most common conceptual approaches to public administration of the cultural sphere:

- "helper" policy - financial support to the middle class is carried out by the state mainly in the form of "counter" subsidies that stimulate private and collective investments in this area (USA); 
- the policy of the "architect" - funding is carried out by the relevant ministry or another state body responsible for the UK, and the GKP becomes an integral part of the general social policy of the state, the purpose of which is to increase the cultural level of the country's population (Western Europe, in particular, France);

- the policy of "engineer" - the state becomes the owner of the material base of the middle class, and the main goals of cultural activities are the issue of upbringing and education (Eastern Europe);

- the policy of "patron" in the state, there are art councils that have the right to receive special state funds and the distribution of these funds between the sub-sectors of culture and art and monitor the non-interference of state institutions in the creative process of organizations and institutions, such financial assistance is received (AngloSaxon countries) [4].

The most effective today in foreign countries have become the "American" and "British" models of state policy (successfully implemented in the USA, Great Britain, Ireland, Finland), which are considered "market" and consist in the allocation of specific goals, content, characteristics and results of state cultural policy. Within the framework of such a policy, the principle of political non-interference in the affairs of the cultural sphere and in decision-making regarding the distribution of financial resources within the region is implemented.

As a result of this approach, the so-called "the arms-length principle" has been formed recently, which provides for the adoption of many managerial decisions in the field of culture with the participation of independent institutions, for example, the National Councils for Arts Affairs (UK), National Endowment for the Arts (USA).

There are analisys of typological models of innovative models in the field of culture (fig. 1).

In modern conditions, when the states are actively pursuing a policy of decentralization, this process is actively spreading to the management of the cultural sphere. In some countries, in particular France, regional directorates for cultural affairs were established, subordinate to the central authorities, and in Denmark and Sweden, separate powers in the field of culture were given to local authorities, but the state retained the right to make decisions on the most important key issues. And in a number of countries, such as Austria, Belgium, Germany, Switzerland, on the contrary, the state carries out only minor coordination or auxiliary functions in the field of management of the cultural sector, and the right to make decisions in the field of regional cultural policy is vested in municipal administrations. 
Creative "reservoirs". Creative "reservoirs" are a set of subjects, ideas, values, knowledge, forms of communication and socialization. These "reservoirs" have a creative potential that significantly exceeds the capacity of enterprises and businesses, and in fact is a new resource. At the heart of creative "reservoirs" are organizational models that are characteristic of network structures.

Creative classes. According to this concept, creative people play a key role as creators of innovations. Professionals working in the sector have three characteristics: technology, talent, and tolerance.
Consumer-driven innovations. Interaction between producers and consumers is a fundamental feature of cultural organizations: these organizations are at the forefront of consuming relevant goods and services and transforming lifestyles, they have a tendency to seek new things and experiment, and a culture of consumption is important.

Mass creativity and innovation (hidden innovation). We are talking about a situation when research (search for new knowledge) and production processes take place in society itself. The cultural sphere influences three spheres of social life: promoting public dialogue, widespread use of new technologies (assistance through creative content) and the need to rethink the national educational model (development of creative and creative skills, inclusion of the education system, development of creative skills, etc.).

Social innovation is the development and implementation of new ideas (goods, services and models) that meet the corresponding needs of society. Unlike other economic agents, cultural organizations tend to have closer ties with the territories in which they operate (local development), and their value system is integrated into the process of social change.

Institutional innovation. Culture plays an important role in fostering the emergence and implementation of institutional innovations through the implementation of international cooperation programs and specific activities aimed at modernizing the content and mechanisms for the provision of public services. Culture "acts" as a resource for local development, its (development) planning and management.

\section{Fig. 1. Typology of innovative models in the field of culture [5].}

The generalized public policy model includes five main elements:

- area of government - sectors and industries that are considered "creative" (for example, visual arts, exhibitions, television and radio broadcasting, film screenings, etc.);

- instruments - means of regulation and support of the cultural sphere (in particular, subsidies, tax benefits, settlement of property issues);

- institutional structure - a set of institutions that regulate relations in the field of culture (for example, a ministry, administration, service, department, etc.);

- decision-making process - a method or method of making decisions on issues that directly or indirectly relate to the sphere of culture;

- the rules, norms and traditions that govern the interaction between the above elements.

In European states, there is a developed mechanism of state financing of the cultural sphere through the introduction of specific taxes (in particular, the tax from the trade in books is used to finance literary activities, the tax on profits of new TV channels - in support of the film industry and the production of audio and video 
products, tax on theater and concert activities - on the development of theatrical art) [6].

In some countries, such as France, Italy, Germany, Great Britain, there is a widespread mechanism for providing loan guarantees to various cultural entities. Also, in most European states, additional sources of funding for the cultural sector are developing, including for such purposes, proceeds from lotteries and gambling, profitable cultural sectors, and the like are used.

In addition, in contrast to the effective management models of the cultural sphere, which are used by developed countries, in Ukraine decisions concerning the sphere of culture are mainly centralized and are made by the relevant state structures.

In contrast to this, in Western realities, the principle of decentralization is being promoted, and the experience of management based on a consultative approach is applied, when decisions are made by special councils, funds, etc., and the state plays only a coordinating role. Of course, in the course of the political association between Ukraine and the EU, the sphere of public administration, including the state, carries reform changes and actively draws on the experience of the EU countries [7].

According to the results of a survey conducted by the German cultural center "Goethe-Institut" in Ukraine, the purpose of which was to identify the differentiation of satisfaction of the needs for cultural services in large and small cities, the main reason why residents of small towns do not attend cultural events is the lack of interesting activities (34\%), lack of funds (28\%) and time (25\%).

At the same time, most of the respondents in large cities (51\%) refer primarily to the lack of time and only $14 \%$ to the lack of interesting events. This underlines the greater concentration and variety of events and events in large settlements compared to small ones. By their nature, the most common cultural and artistic events in big cities are concerts, in small ones - exhibitions [8].

In general, the sphere of culture in Ukraine is at the stage of modernization and renewal in accordance with European values and aspirations for integration into the world community, and also requires certain changes in the direction of reform.

In this context, in recent years, the following key areas of reform in the field of culture have been implemented:

- reform of legislation on the protection of monuments;

- creating incentives for filmmaking; financing of cultural events;

- introduction of a contract system in theaters and cultural institutions.

Taking into account the main priority directions of development of the sphere of culture, on February 1, 2016, a long-term strategy for the development of Ukrainian culture was adopted - a strategy of reforms that will contribute to the modernization of the system of financing and economic support of the sphere of culture, 
decentralization of management of the sphere of culture, the formation of a national cultural product and the creation of a single information and cultural space [9].

Discussion. The current state of culture in Ukraine requires new political approaches, measures and mechanisms for their implementation. The development of the culture of the state and its individual regions should be a definite one of the main directions of activity of state authorities and local self-government bodies. Accordingly, the following goals and priorities in public policy can be noted:

- drawing up and approving a permanent program for the development of the culture of Ukraine, as well as support in the development of medium-term regional programs for cultural development;

- introduction of the public into the processes of management and control in the field of culture;

- development of an effective model of financial and material and technical support for cultural development;

- preparation, adoption and state social standards for the provision of services to the population that are guaranteed by the state in the field of culture;

- implementation of a set of educational, cultural and artistic programs, as well as projects for the younger generation;

- support and development of rural culture;

- Ukraine's participation in international cultural projects, processing of a set of information and cultural events to inform the world about the cultural values of Ukraine.

Among the main models of state financing of the cultural sphere, the work analyzes those that have received conditional names: the state-inspirer, the statepatron, the state-architect and the state-engineer. It is also very important that the same country can simultaneously use additional models, therefore the proposed classification is not mutually exclusive.

Therefore, for Ukraine, there may be a promising model of the "patron" state, where the financing policy "at arm's length" corresponds to modern international trends, is characterized by the processes of decentralization and regionalization of cultural policy, which usually correspond to social development strategies.

It is in European practice that culture is not just an object of public administration, but is also considered as the basis for further socio-economic growth of the state, since it plays an important role in many aspects of the development of the state, in particular:

- in the development of intellectual resources of the state economy (ensuring the employment of citizens in the creative sectors, developing innovative potential in the state, stimulating innovation to ensure the production of competitive and high-quality products); 
- in the sustainable development of the economy (dissemination of the latest digital technologies, strengthening the relationship between the cultural, economic and environmental components of sustainable development of territorial communities); - in the socially oriented development of the economy - culture is the basis for the development of the economy through the strengthening of intercultural dialogue and respect for cultural diversity;

- increasing the level of social cohesion in the process of cultural activities, increasing the role of the public sector in the social, cultural, economic development of the country.

Conclusions. The state policy in the sphere of culture should be an important element of the integration strategy of the policy of the European integration strategy. In the period of changes and development of market relations, integration transformations, changes in legislation, foreign experience in ensuring the social sphere can be used and somewhat adopted, focusing on the main problems of the cultural sphere, because foreign experience solves not only the issues of practical implementation, but also the solution of current problems. The states that drew attention to the need for state regulation of the cultural sphere were such highly developed countries such as Germany, France, Italy, Spain and others. Therefore, the work considers the experience of these countries at the level of state regulation for the development of the cultural sphere.

The conclusion on diversification of the mechanism of financing the sphere of culture in Ukraine, which is implemented mainly through budgets of different levels, is insufficient. For comparison, in foreign countries it is practiced to finance the sphere of culture by introducing specific taxes, providing guarantees for loans to subjects, searching for additional sources of financing.

The conclusion is that in Ukraine it would be advisable to create cultural centers, should be financed from state grants. It is advisable to impose obligations on these centers to create a network with other regional cultural centers, which would make it possible to create motivation for their pooling in terms of resources and the implementation of joint projects. The best centers could receive awards for achievement, strategic business plans, business models, community engagement or governance.

The innovation identified a project to create functional and regulatory provisions in Ukraine that oblige the authorities at the regional and local levels to attract leaders through an open competition and training in the field of cultural management to create opportunities for the cultural and social development of the state. It is worth organizing a meeting for the cultural centers and the cultural administration of the regional government to exchange experiences and discuss strategic development. 
The indicated directions for the implementation of public policy are an opportunity to demonstrate the best examples or promising initiatives, as well as in the context of communication between cultural managers.

\section{References:}

1. Karlova, V. (2003), Derzhavna polityka u sferi kultury: sutnist ta osoblyvosti realizaciji v suchasnyh umovah [State policy in the field of culture: the essence and features of implementation in modern conditions: author. dis. 25.00.01 "Theory and history of public administration"]. Kyiv, $20 \mathrm{p}$.

2. Akimov, O. O., Troschinsky, V. and Karpa, M. I. and Stefanyk, V. and Ventsel, V. and Akimova, L. M. (2020), Intrenational Experience of the Public Administration in the Area of National Security. Journal of Legal, Ethical and Regulatory. Issues (23).

3. The Verkhovna Rada of Ukraine (1996), The Law of Ukraine "Constitution of Ukraine", retrieved from : https://zakon.rada.gov.ua/laws/show/254\%D0\%BA/96-\%D0\%B2\%D1\%80.

4. Dorosh, T. (2011), Osnovni pryncypy dergavnogo upravlinnya sferoju kultury [Basic principles of public administration in the field of culture]. Actual Problems of Public Administration, № 2 (40), P. 149 - 156.

5. Rausell Köster, P. Abeledo Sanchís R. Boix Sempere, R. Marco Serrano, F. (2012). The Culture as a factor for economic and social innovation, Project report, Tome 01, p. 21. retrieved from : https://www.uv.es/soste/ pdfs/Sostenuto_Volume1_ENG.pdf.

6. Ignatchenko, I. (2013), Osoblyvosti realizaciji dergavnoji polityky Ukrainy u cferi kultury : suchasnyj stan ta svitovi standarty [Features of the implementation of state policy of Ukraine in the field of culture: current status and world standards], Theory and practice of law, Issues 1 . retrieved from : http://nbuv.gov.ua/UJRN/tipp_2013_1_16.

7. Karpa, M. (2018), Reformuvannya dergavnoji slugby v Ukrajini v konteksti politychnoji asociaciji mig Ukrainoju ta ES (kompetencijnyj vymir) [Civil service reform in Ukraine in the context of the political association between Ukraine and the EU (competence dimension)], Efficiency of public administration, LRIDU NADU, I ssue 3 (56), Part 1, P.184-193.

8. Shykerynets, V. Vychivsky P. (2019), Rozvytok sociokulturnoji sphery yak vaglyvyj chynnyk vyrishennya regionalnyh problem [Development of socio-cultural sphere as an important factor in solving regional problems], Carpathian region. Scientific studies in history, culture, tourism, №12-13, pp. 202-209.

9. The Cabinet of Ministers of Ukraine (2016), Order of the Cabinet of Ministers of Ukraine "On approval of the Long-term strategy for the development of Ukrainian culture - reform strategy”, 1 February, № 1192016-r, retrieved from: http://zakon5.rada.gov.ua/laws/show/119-2016-\%D1\%80.

Received: August 10, 2020 Approved: September 15, 2020 